\title{
Differentiation of physical and mechanical properties analysis of self made gypsum product with raw material from Tasikmalaya with standar ISO and factory made
}

\author{
Wahyuning AP, Zulia Hasratiningsih, Rosida Manurung \\ Department of Dental Material Science \&Technology Faculty of Dentistry Universitas Padjadjaran
}

\section{ABSTRACT}

In early research, gypsum's product from Padalarang and Tasikmalaya had been compared and it is found that Tasikmalaya gypsum was better. In these research, it's used gypsum product from Tasikmalaya with wet calcination method using autoclave. This research consisted of four samples divided into three control groups and one treatment group. Research's sample consisted of 45 units and 15 units data from the last research. To compared physical and mechanical properties, every samples was tested in three treatments. Research results showed that the average setting time, setting expansion and compressive strength of wet calcination gypsum product are respectively 487.6 seconds, $0.492 \%$, and $12.708 \mathrm{Mpa}$. The results were statistically analyzed with MANOVA and Tukey test. The analysis showed differences in physical and mechanical properties between self made gypsum product from Tasikmalaya with Padalarang's and two marketed gypsum products. Setting time self made gypsum product meets the ISO for type III, while compressive strength and setting expansion were not. But gypsum's production from Tasikmalaya done by wet calcinations had better physical and mechanical properties, so it can be used in dentistry.

Key words: Tasikmalaya's gypsum, autoclave, setting time, setting expansion, wet compressive trength

\section{INTRODUCTION}

Gypsum or plaster products are used in many aspects of daily life such as for construction, interior industry and dentistry. ${ }^{1-4}$ In dentistry, the plaster products are divided into five types including Type I (impression plaster), Type II (model plaster), Type III (dental stone), Type IV (high strength-low expansion stone), and Type $\mathrm{V}$ (high strength-high expansion stone). $.1,2,5,6$ These plaster products are produced by dehydrating dihydrate to produce calcium sulphate hemihydrate $\left(\mathrm{CaSO}_{4} \cdot \frac{1}{2} \mathrm{H}_{2} \mathrm{O}\right)$ by using various methods. ${ }^{6-8}$

One of the methods used is wet heating using autoclave that has been patented by Randel and Dailey in 1933. The first step is placing plaster blocks into autoclave and heating them with 117$212 \mathrm{Kpa}$ pressure in a temperature of $120-147^{\circ} \mathrm{C}$ for 5-7 hours. After the heating process finished, plaster product blocks dried in a temperature of $\pm 100^{\circ} \mathrm{C}$ and then crushed and refined so that a particle of $100-200$ mesh is gained. The finer the particle resulted, the better the plaster product. 3,9-15

Another method used is the dry heating, which is by heating dihydrate that has been crushed in a temperature of $110^{\circ} \mathrm{C}$. If the heating is continued up to $130-140^{\circ} \mathrm{C}$ then most dihydrate 
Calcium sulphate dihydrate + heat Calcium sulphate hemihydrate + water vapor

$$
2 \mathrm{CaSO}_{2} \cdot 2 \mathrm{H}_{2} \mathrm{O}+\text { heat }+(\mathrm{CaSO} 4)_{2} \cdot \mathrm{H}_{2} \mathrm{O}+3 \mathrm{H}_{2} \mathrm{O}
$$

has changed into hemihydrate. When the heating process is continued to $150-190^{\circ} \mathrm{C}$, the dihydrate in this process has changed completely into soluble anhydrate. If the heating is increased to over $205^{\circ} \mathrm{C}$ the water contained in the plaster will practically missing and the product produced is known as "dead-burned" plaster. ${ }^{14,16,17}$

The dental stone is produced using wet heating method under pressure in a close container. This method will produce a more regular particle in a more uniform shape and less porous. The particle shape in the dental stone is an acalcium sulphate hemihydrate that is frequently used for laboratory need that requires a plaster with high strength and hardness, while from dry heating the end product is plaster with irregular shapes, non uniform and more porous which is also weaker than then plaster product from the wet heating. Plaster and dental stone has a similar basic chemistry structure. The difference is only in size, shape and porosity of the particle produced by using different methods. $8,9,18-20$,

Hadikrishna ${ }^{20}$ has performed a study using wet heated plaster product using raw materials from Padalarang while Mujahid ${ }^{8}$ has performed a study using dry heated plaster using raw materials from Padalarang and Tasikmalaya. From the study performed by Mujahid ${ }^{8}$, it is revealed that the self manufactured plaster product made from raw materials from Tasikmalaya is excelled in its physical and mechanical properties compared to the plaster made from raw materials from Padalarang. There has not been any study performed to get plaster product using wet heating method using raw materials from Tasikmalaya when the product of wet heating is known as having better physical and mechanical properties compared to dry heated plaster product.

Based on that reason, the author has the urge to make a self made plaster product using raw materials from Tasikmalaya and a wet heating method which is a bit different from what is done by Hadikrishna ${ }^{20}$ The difference is in the pressure and temperature used during heating. The increased pressure and temperature is aimed at gaining a denser product particle so that a plaster with better properties from the self made wet heated plaster made form raw materials from Padalarang will be produced. Furthermore, the product produced from this study will be compared with the plaster usually used in the Faculty of Dentistry, Universitas Padjadjaran, in terms of its physical and mechanical properties.

\section{MATERIALS AND METHODS}

Sample for this research was collected in the form of blocks that is purchased from Karang Nunggal village, Tasikmalaya, West Java. For control, a commercial plaster "Siam Gypsum" brand and a dental stone "Hinrizit B Blue" brand are used. In this sample, three tests were performed, i.e. during hardening, hardening expansion and wet tension strength. Five samples were used during each test.

The self made plaster is made using wet heating method. The first thing to do is crushing the plaster blocks using crusher so that plaster powder with smaller particle will be produced which is then filtered using 50-200 mesh strainer. The filtered plaster powder is put in a container made of mesh layered by filter paper. The containers are then put in an autoclave that had been filled by distilled water and a temperature of $125^{\circ} \mathrm{C}$ and a pressure of $150 \mathrm{KPa}$ are applied for 6 hours. The plaster heated is then removed and washed using $96 \%$ alcohol with a temperature of $60^{\circ} \mathrm{C}$. The washed plaster product is then placed in an aluminum container and then dried in an oven with a temperature of $110^{\circ} \mathrm{C}$ for 14 hours. The plaster is then placed in a dessicator to cool it. Grind the cool plaster product using a grinder and filter it using a 100-200 mesh strainer. The final product is placed in a tight closed container so that it will not be polluted by the outside air.

The sample produced is then tested using three tests, i.e. test for hardening time, hardening expansion and test for wet tension strength. For hardening time, the test is performed using Vicat apparatus. The first step to do is weighing 200 gram of plaster product. A mixture is then made using $\mathrm{a} \mathrm{w} / \mathrm{p}$ ratio of 0.4 for self made plaster from Tasikmalaya, $w / p$ ratio of 0.5 for plaster while for dental stone $\mathrm{a} w / \mathrm{p}$ ratio of 0.3 . Then the mixture 
is placed into a cone shape mold with a glass slab as the base until the mold is full. The plaster in the mold is then placed on the test table. The penetration test is started after the loss of gloss period (a condition where the plaster product mixture becomes dull which is a sign that the plaster starts to harden). The needle is dropped into the sample and is repeated with an interval of 15 seconds until the needle cannot penetrate the mixture for $2 \mathrm{~mm}$ deep. In each repetition, the needle is cleaned and the mixture is moved to find a new test area. The time needed since the mixing of the powder and water up to the point where the needle cannot penetrate the mixture for $2 \mathrm{~mm}$ is measured (this time is called the Vicat hardening time).

The sample for hardening expansion test is made by weighing 100 gram of plaster powder. Then a mixture with a w/p ratio of 0.4 for self made plaster product from Tasikmalaya, a w/p ratio of 0.5 for plaster, a w/p ratio of 0.3 for dental stone are made. After that, place the plaster mixture in the extensometer until full and keep it in a room temperature for 2 hours. The hardening expansion measurement is performed by observing the movement of needle in the dial gauge. Firstly, perform initial reading, i.e. 1 minute before tested plaster setting time. And then after 2 hours since the plaster and water mixture, perform the final reading. Note and count the differences of number pointed by dial gauge needle.

The sample for wet tension strength testing is started by making mixture as the one used in the hardening expansion test sample. After the mixture is ready, pour it in a cylindrical mold with a glass slab as the base until it is full and then level it. Sample is placed in a room temperature and removed from the mold after 45 minutes. The test is performed after 1 hour since the mixing of powder and water. The test is conducted using tension strength test instrument. The sample is placed on the test table under the pressure instrument until the moveable endpiece contacts the sample. Increasing loads are then given continuously and smoothly without any shock until a crack or breakage is found in the sample. The amount of force that causes the sample to break or crack is then noted.

Tasikmalaya plaster, plaster crushing using crusher, filtering using 50-200 mesh strainer, heating using autoclave, washing with alcohol, drying in an oven, cooling in a dessicator, grinding using a grinder, filtering using 100-200 mesh strainer, sample making, hardening time test, hardening expansion test, wet strength test.

\section{RESULTS}

Data from the study is used to see the difference in the physical and mechanical properties of the self made plaster product using raw materials from Tasikmalaya, self made plaster product using raw materials from Padalarang, commercial plaster and commercial dental stone. From these four sample groups, three of them, i.e. self made plaster product made of raw materials from Padalarang, commercial plaster and dental stone were the control groups. The study sample consisted of 45 units and to compare the study results, data from previous study, i.e. 15 samples that were self made plaster product made of raw materials of Padalarang, were also used. Three treatments were applied, i.e. measurement of hardening time, hardening expansion and wet tension strength. Each treatment was applied to 20 samples. The analysis used was a comparative one using Multivariate Analysis of Variance (MANOVA) followed by Post Hoc Test Tukey to see the correlation among the three sample groups.

\section{DISCUSSION}

This study about the physical and mechanical properties of self made plaster using wet heating methods with raw materials from Tasikmalaya refers to a previous research performed by Hadikhrisna ${ }^{20}$ The difference in this study is only in the heating method for the plaster and the place where the raw materials are originated. The heating performed by Hadikrishna ${ }^{20}$ is performed in an autoclave with a pressure of $125 \mathrm{Kpa}$ and temperature of $117^{\circ} \mathrm{C}$ for 7 hours while the method for this study used an autoclave with a pressure of $150 \mathrm{Kpa}$ and temperature of $125^{\circ} \mathrm{C}$ for 6 hours. The increased temperature and pressure is The increased temperature and pressure is aimed at getting higher powder density so that it is expected that better properties will be gained. $3,11,22$

Raw materials used in the previous study was collected from Padalarang while this study 
Table 1. Comparison of physical and mechanical properties of the self made plaster product made of raw materials from Tasikmalaya, Padalarang, commercial plaster and dental stone.

\begin{tabular}{ccccccccc}
\hline \multirow{2}{*}{ Material } & \multicolumn{2}{c}{ Tasikmalaya } & \multicolumn{2}{c}{ Padalarang } & \multicolumn{2}{c}{ Plaster } & \multicolumn{2}{c}{ Dental Stone } \\
\cline { 2 - 8 } & Average & SD & Average & SD & Average & SD & Average & SD \\
\hline $\begin{array}{c}\text { Testing during the } \\
\text { hardening (second) }\end{array}$ & 487.600 & 7.503 & 220.000 & 14.018 & 1221.400 & 10.479 & 634.000 & 15.427 \\
$\begin{array}{c}\text { Hardening expansion } \\
\text { testing (\%) }\end{array}$ & 0.492 & 0.022 & 0.176 & 0.015 & 0.234 & 0.015 & 0.260 & 0.012 \\
$\begin{array}{c}\text { Wet-push power test- } \\
\text { ing, Replication (Mpa) }\end{array}$ & 12.708 & 0.384 & 7.680 & 0.438 & 10.680 & 0.402 & 28.220 & 0.939 \\
\hline
\end{tabular}

used raw materials from Tasikmalaya. To find out whether the plaster product from Tasikmalaya can harden or not, a preliminary study was performed and it was revealed that the heated raw materials from Tasikmalaya could harden but the ratio of water and powder needed was beyond the range proposed for dental stone, i.e. $0.28-0.30 .^{19,24}$

The ratio of water and powder used in the self made plaster product to get a workable mix is 0.40 . This high ratio is caused by lower density of particles in the self made plaster compared to dental stone. Dental stone has a regular particle shape, relatively non porous, and has powder that is denser that reduce the amount of water needed. ${ }^{3,19,22}$

Meanwhile, using a similar heating method, this self made plaster from Tasikmalaya has a water and powder ratio that is lower compared to the self made plaster from Padalarang that needs a water and powder ratio of 0.5 . The high water and powder ratio will affect the physical and mechanical properties of the plaster product because it will lengthen the hardening time, reduce strength and also the hardening expansion. 3,11,19

Average Vicat hardening time for self made plaster product from Tasikmalaya is $\mathbf{4 8 7 . 6}$ seconds or 8 minutes 7 seconds while the average hardening time of the self made plaster product from Padalarang is 220 seconds or 3 minutes 40 seconds, for plaster it is 1221.4 seconds or 20 minutes 21 seconds and for dental stone it is 634 seconds or 10 minutes 34 seconds. From the average hardening time above, the self made plaster can be included into the time range of dental stone hardening according to ISO. ${ }^{11}$ while the plaster product from Padalarang has a very short hardening time. This may be caused by the high amount of contaminations in the plaster composition. At the time the plaster powder is mixed with water, the pure gypsum will act as crystallization cores. The more crystallization cores found, the more inter-crystal interactions found and the faster the hardening reaction is..$^{3-5}$ Average hardening expansion in self made plaster is $0.492 \%$. This high hardening expansion rate makes self made plaster dismissed from the range of dental stone hardening expansion which is 0 $0.2 \%$ according to ISO 6873:1998(E). Theoretically, the higher the ratio of water and powder used, the smaller the plaster product hardening expansion is. However, the high water to powder ratio used in this study does not cause smaller hardening expansion. The high hardening expansion may be caused by the composition of the plaster product that contains several contaminators such as calcium and magnesium carbonate, allumina, feroxide, silica oxides, clay, and some soluble salts. ${ }^{9,15,16}$ The tension strength in this research is measured using the methods approved by ISO 6873:1998(E). The tension strength measurement is performed one hour since water and powder mixing that the strength gained is the wet tension strength where there is still some residual mixing water when the plaster is already hardened and ready to be tested. ${ }^{3,17}$

The average tension strength of the self made plaster is $12.708 \mathrm{Mpa}$ while the tension strength needed by a dental stone is at least 20 Mpa. The tension strength of the self made plaster is still much smaller compared to the dental stone according to the ISO standard range. This may caused by the high ratio of water and powder used in the self made plaster product that creates more pores and a decrease in the strength of the plaster product. ${ }^{3,17}$

Based on this study, it is revealed that 
the physical and mechanical properties of self made plaster from Tasikmalaya still show some disadvantages. This may be due to the fact that during the manufacturing, the Tasikmalaya plaster product does not contain additive to get preferred physical and mechanical properties.

\section{CONCLUSION}

Based on the results of the study performed, it can be assumed that: The hardening time of the self made plaster that is made of raw materials from Tasikmalaya is in the range of dental stone hardening time according to ISO and it is faster than commercial plaster and longer than the self made plaster using raw materials from Padalarang. The hardening expansion of the self made plaster product from Tasikmalaya has the highest value compared to the three control groups. The wet tension strength of the self made plaster from Tasikmalaya is smaller compared to the dental stone but higher than the commercial plaster and self made plaster from Padalarang. The self made plaster from Tasikmalaya has physical and mechanical properties that are better than the self made plaster from Padalarang. This self made plaster can still be used for laboratory work procedures that do not need high strength and accuracy requirements such as display making, study model base making and cuvette filling procedure.

\section{REFERENCES}

1. Anusavice KJ. Phillip's science of dental materials. $11^{\text {th }}$ ed. Philadelphia: W.B. Saunders Co.; 2003. p. 256-68,271-9.

2. Kroschwitz Jl. Kirk-Othmer encyclopedia of chemical technology. $4^{\text {th }}$ ed. New York: A Wiley-Interscience Publication; 1993.

3. O'Brien WJ. Dental materials and their selection. $3^{\text {rd }}$ ed. Carol Stream: Quintessence Publishing Co. Inc.; 2002. p. 37-46.

4. Phillips RW. Science of dental materials. London: W.B. Saunders Co.; 1991. p. 69-70.

5. Hatrick CD, Eakle WS, Birds F. Clinical applications for dental assistants and dental hygienists. St. Louis: W.B. Saunders; 2003. p. 231-3,237-8.

6. Manappallil JJ. Basic dental materials. $2^{\text {nd }}$ ed.
India: Jaypee Brother Medical Publisher Ltd.; 2003. p. 82-92,96-7.

7. Darvell BW. Materials science of dentistry. $6^{\text {th }}$ ed. Pokfulam: Darvell B.W.; 2000. p. 35,48.

8. Mujahid M. Perbandingan sifat fisik dan mekanik gips plaster olahan sendiri dengan bahan baku dari Padalarang dan Tasikmalaya. Bandung: Fakultas Kedokteran Gigi Universitas Padjadjaran.

9. American Dental Association. Guide to dental materials and devices. $7^{\text {th }}$ ed. American Dental Association; 1974. p. 225-60.

10. Anderson JN. Applied dental materials. $2^{\text {nd }} e d$. Oxford: Blackwell Scientific Publication; 1972. p.167-84.

11. Combe EC. Notes on dental materials. $6^{\text {th }}$ ed. Edinburgh; Churchill Livingstone; 1992. p.10, 118,187-9.

12. Eberl JJ, Ingram AR. Process for making high-strength plaster of Paris. Industrial and Engineering Chem; 1949. 41,1061-5.

13. Fraunhofer JA. Scientific aspect of dental materials. London: Butterwoths; 1975. p. 4012, 404.

14. Kirk RE, Othmer DF. Encyclopedia of chemical technology. $4^{\text {th }}$ ed. New York: A WileyInterscience Publication; 1992(4):813-22.

15. Williams DF, Cunningham J. Materials in clinical dentistry. Toronto: Oxford University Press; 1979. p. 226-7.

16. Hasratiningsih Z. Phase and strength changes of gypsum in the dental lost method. Thesis. Sydney: Department of Prosthetics Dentistry, University of Sydney; 1987.

17. Leighou RB. Chemistry of engineering materials. $4^{\text {th }}$ ed. New York: Mc Graw Hill Book Co. Inc.; 1942. p. 482-4.

18. Craig RG, Powers JM, Wataha JC. Dental materials properties and manipulation. $7^{\text {th }}$ ed. St. Louis: C.V. Mosby Co.; 2000. p. 189,190,197.

19. Furnas CC. Roger's industrial chemistry. $6^{\text {th }}$ ed. New York: D Van Nostrad Co. Inc.; 1943. p. 873-5.

20. Hadikhrisna I. Sifat fisik dan mekanik produk gips metode pemanasan basah olahan sendiri dengan bahan baku dari Padalarang. Bandung: Fakultas Kedokteran Gigi Universitas Padjadjaran; 2005.

21. Gladwin M, Bagby M. Clinical aspect of dental 
materials. Philadelphia: Lippincot William and Wilkins; 2000. p. 108-10.

22. Phillips RW, Moore BK. Elements of dental materials. London: W.B. Saunders Co.; 1994. p. $40-8,51-5$.

23. International
Standard
Organization.
International standard: ISO 6873 dental gypsum products. $2^{\text {nd }}$ ed. Geneve: International Standard Organization; 1988. p. 1-11.

24. Craig RG, Powers JM. Restorative dental materials. $11^{\text {th }}$ ed. St. Louis: C.V Mosby Co.; 2002. p. 392-9,401-6. 